\title{
PERBAIKAN MUTU KAKAO ASAL SOMATIK EMBRIOGENESIS MELALUI SAMBUNG SAMPING DENGAN KLON KAKAO UNGGUL LOKAL
}

\section{Improving The Quality of Cocoa from Somatic Embryogenesis Through Side Grafting with Local Superior Cocoa Clones}

\author{
Salim, Andi Faisal Suddin, dan Jermia Limbongan \\ Balai Pengkajian Teknologi Pertanian Sulawesi Selatan \\ Jl. Perintis Kemerdekaan KM.17,5 Makassar \\ e-mail: andifaisals@yahoo.co.id
}

Received: 20 Mei 2021; Accepted: 10 Juni 2021; Published: 25 Juni 2021

\begin{abstract}
ABSTRAK
Hasil penelitian beberapa tahun sebelumnya menyimpulkan bahwa tanaman kakao asal somatik embriogenesis (SE) tahun tanam 2009 dan 2012, pertumbuhan dan produksinya belum optimal. Bertolak dari data dan informasi tersebut, maka perlu upaya teknologi peningkatan produksi dan mutu kakao asal SE melalui sambung samping. Tujuan penelitian ini meliputi: a) untuk menganalisis peningkatan kualitas tanaman kakao asal SE melalui sambung samping, b) untuk menganalisis tanggapan dari petani terhadap peningkatan kualitas tanaman kakao asal SE melalui sambung samping. Penelitian ini dilaksanakan di Bone dan Luwu Sulawesi Selatan mulai Januari - Desember 2017. Penelitian ini dilakukan dengan rancangan split plot dengan petak utama lokasi kegiatan, anak petak perlakuan klon diulang 4 kali. Data yang dikumpulkan mellui pengamatan di lapang. Data yang telah dikumpulkan, ditabulasi dijelaskan, dan dianalisis dengan ANOVA dan Duncan Multiple Range Test (tingkat 5\%). Hasil penelitian menunjukkan petani yang mengusahakan tanaman kakao SE dan melakukan sambung samping dengan klon kakao unggul lokal mempunyai karakteristik usia produktif dan didukung tingkat pendidikan serta pengalaman yang memadai. Pertumbuhan tanaman kakao SE yang disambung dengan klon kakao unggul lokal baik jenis maupun lokasinya memberikan pengaruh beda nyata. Demikian juga petani yang telah mencoba menyambung secara mandiri tanaman kakao SE dengan klon kakao unggul lokal memberikan hasil yang lebih baik. Respon petani terhadap tanaman kakao SE yang disambung dengan sumber entris klon kakao unggul mencapai $60 \%$ sudah melakukan sambung samping. Produktivitas kakao SE yang disambung samping mencapai $1.988 \mathrm{~kg} / \mathrm{ha}$. Perbaikan tanaman kakao SE dengan sambung samping memerlukan biaya mencapai Rp. 4.675.000/ha, lebih murah dibandingkan dengan penanaman ulang dengan sambung pucuk mencapai Rp. 13.660.000/ha.
\end{abstract}

Kata kunci: Kakao, unggul lokal, sambung samping

\section{ABSTRACT}

The results of the previous year's study found that growth and production of somatic embryogenesis (SE) cacao, planting in 2009 and 2012, is not optimal. Based on this information, so there is a need for engineering efforts to increase the production and quality of $S E$ cocoa through side grafting applications. The objectives of this research are: a) to analyze the quality improvement of cocoa plant origin SE through side grafting, $b$ ) to analyze the responses from farmers to improve quality of cocoa plant origin SE through side grafting. This research was conducted in Bone and Luwu South Sulawesi from January to December 2017. This research was done with split plot design with main block location activity and, 4 treatments from clone cocoa and repeated 4 times. Data to be collected from abservation at field. The data that has collected, tabulated is described, and analyzed with ANOVA and Duncan Multiple Range Test (5\% level). The results showed that farmers working on SE cocoa and side grafting with local superior cocoa clones 
had characteristics of productive age and supported by adequate education and experience. The growth of SE cocoa planted with superior local cocoa clones of type and location gives a significant difference. Similarly, farmers who have tried to side grafting of SE cocoa with superior local clones provide better results. Reached $60 \%$ farmers has done side grafting of SE cocoa with superior local cocoa clones. Productivity of grafted SE cocoa plant are 1,988 kg/ha. Improvement of SE cacao plants with side grafting costs Rp. 4.675.000 / ha, cheaper than replanting with shoots reach Rp. 13.660.000/ ha.

\section{Keywords: Cocoa, local superior, side connection}

\section{PENDAHULUAN}

Pembangunan perkebunan ke depan harus dilandasi optimasi sumberdaya yang dicirikan dengan keterpaduan kegiatan, lokasi, pembiayaan maupun komoditas. Rancang bangun pewilayahan dan pengembangan kawasan produksi komoditas strategis dan komoditas unggulan nasional perlu bersifat komprehensif. Pendekatan pengembangan kawasan perkebunan dirancang untuk meningkatkan efektifitas dan efisiensi kegiatan, serta mendorong keberlanjutan kawasan komoditas unggulan perkebunan (Permentan, 2012).

Tanaman kakao sebagai komoditas unggulan Sulawesi Selatan memiliki nilai ekspor yang cukup tinggi. Komoditas kakao ini memiliki sentra pengembangan produksi di seluruh wilayah Sulawesi Selatan. Pertimbangan utama penentuan sentra pengembangan produksi dengan memperhatikan kesesuaian agroekosistem (Basir, et al., 2013).

Komoditas kakao merupakan bahan pangan penting dan strategis dalam kancah perekonomian Indonesia. Sampai saat ini komoditas tersebut masih memerlukan perhatian besar pemerintah karena produksi dalam negeri belum mampu mencukupi kebutuhan nasional maupun ekspor.

Masalah utama pengembangan komoditas kakao antara lain; rendahnya produktivitas dan kualitas hasil. Penyebab utama rendahnya produktivitas dan kualitas hasil diantaranya adalah kurang optimalnya pengelolaan tanaman di on farm, penggunaan dan penerapan inovasi teknologi budidaya belum optimal antara lain keterbatasan bibit bermutu dan varietas unggul, serta teknologi produksi (Limbongan, et al., 2010; Basir, et al., 2013) dan pemanfaataan bahan organik dalam usaahataninya.

Dalam rangka mendukung program swasembada pangan khususnya pada komoditas kakao tersebut, maka Badan Litbang Pertanian melalui Pusat Penelitian dan Pengembangan Perkebunan sejak tahun 2009, mencanangkan kegiatan Gerakan Peningkatan Produksi Kakao Nasional (Gernas Kakao). Program Gernas kakao menitik beratkan pada program peremajaan, rehabilitasi, intensifikasi dan ekstensifikasi.

Bahan tanam dengan hasil teknologi tinggi melalui perbanyakan SE perlu mendapat dukungan penanganan yang intensif. Pemanfaatan teknologi tersebut juga harus didukung dengan memanfaatkan pupuk organik.

Hasil biji kakao sebagai nilai manfaat dari kegiatan usahatani merupakan hal yang sangat diharapkan oleh petani. Pengelolaan untuk memberikan nilai tambah dan daya saing merupakan upaya peningkatan pendapatan dan kesejahteraan petani.

Balai Pengkajian Teknologi Pertanian (BPTP) sebagai Unit Pelaksana Teknis Badan Litbang Pertanian di daerah, mempunyai tugas sesuai dengan Surat Keputusan Menteri Pertanian RI No 350-KPTS-OT.210/6/2001 tertanggal 14 Juni 2001 tentang tugas dan fungsi BPTP propinsi Sulawesi Selatan. Sehingga pada tahun 2017, salah satu kegiatan untuk mengintervensi pengembangan komoditas kakao adalah melakukan kajian teknologi spesifik lokasi di Sulawesi Selatan.

Produktivitas perkebunan kakao masih tergolong rendah, yaitu di bawah potensi hasil penelitian. Peningkatan produktivitas dapat ditempuh melalui 6 pendekatan yaitu; a) pendekatan peremajaan tanaman sudah rusak, b) rehabilitasi tanaman yang sudah tua, c) ekstensifikasi tanaman, d) instensifikasi tanaman melalui pemeliharaan, pengendalian hama penyakit, sanitasi, e) penanganan hasil yang intensif, dan f) pemberdayaan kelembagaan petani. Beberapa hasil kajian yang telahdilaksanakan oleh Limbongan, et al . (2015) menunjukkan luas areal kakao SE di Sulsel sejak tahun 2009-2012 tlah mencapai 6.000 ha dengan berbagai kedala antaral lain; produksi rendah, jorget tinggi, biji kecil, dan lain-lain (Limbongan, 
et al, 2016). Beberapa teknologi misalnya sambung samping, sambung pucuk, penggunaaan bioslury dan lain-lain, telah terbukti dapat meningkatkan produksi dan kualitas buah kakao (Limbongan, et al., 2016).

Dengan menerapkan teknologi-teknologi tersebut di atas petani kakao tidak mengalami kehilangan hasil sebaliknya dapat meningkatkan hasil kakao dan menggunakan klon-klon unggul lokal sebagai sumber bahan tanam serta memanfaatkan limbah tanaman sebagai sumber pupuk organik. Agar petani dapat menerapkan teknologi-teknologi tersebut dengan baik, perlu ada kegiatan pengkajian perbaikan mutu kakao asal Somatik Embriogenesis melalui sambung samping dengan menggunakan klon kakao unggul lokal sebagai batang atas.

Penelitian bertujuan untuk menganalisis aplikasi teknologi sambung samping pada tanaman kakao asal SE dengan klon unggul lokal, untuk mengetahui respon petani terhadap teknologi sambung samping dan untuk mengetahui struktur biaya sambung samping dan sambung pucuk pada tanaman kakao.

\section{METODE PENELITIAN}

Penelitian ini dilaksanakan di Kabupaten Bone dan Kabupaten Luwu, Provinsi Sulawesi Selatan, mulai Januari sampai Desember 2017.

Metode penelitian dengan rancangan split plot dengan petak utama lokasi kegiatan, anak petak perlakuan sambung samping dengan klon kakao unggul dan diulang 4 kali (ulangan dilakukan oleh petani). Perlakuan yang dicobakan adalah a) perlakuan A : Sambung samping dengan $S-1$, b) perlakuan B : sambung samping dengan $\mathrm{S}-2, \mathrm{c}$ ) perlakuan $\mathrm{C}$ : sambung samping dengan MCC-01, dan d) perlakuan D : sambung samping dengan MCC-02. Pemilihan lokasi pengkajian dilakukan dengan pertimbangan bahwa; a) lokasi pengembangan perkebunan kakao SE, b) kelompok tani pelaksana pengembangan perkebunan kakao SE yang aktif, dan c) Gapoktan/Kelompok Tani/Petani mempunyai motivasi untuk mengintroduksi teknologi produksi komoditas perkebunan kakao SE, d) serta hasil konsultasi dan koordinasi dengan Tim Teknis kabupaten.

Pengumpulan data dilakukan secara berkala dari hasil pengamatan dan abservasi di lapang, serta komunikasi dengan tim teknis pengembanagan kawasan perkebunan kakao yang berada di kabupaten. Data yang dikumpulkan meliputi; a) pertumbuhan tanaman, b) produksi, c) karakteristik petani dan kinerja koordinasi pelaksana di lapang, d) kerawanan serangan hama, e) dan f) penerapan teknologi produksi kakao.

Analisis data dilakukan dengan analisis kuantitatif dan kualitatif. Analisis kuantitatif dimaksudkan ada tidaknya perbedaan nilai antara perlakuan yang dilakukan kegiatan (Istijanto, 2010). Data kuantitatif dapat disebut data berupa angka dalam arti yang sebenarnya yang mana dibagi menjadi dua yakni data interval dan rasio (Singgih Santoso dan Fandy Tjiptono, 2002). Berdasarkan tujuan pengkajian dan manfaat dari pengkajian, maka untuk menguji hipotesis pada pada tujuan pengkajian digunakan metode analisis statistik.

Data yang terkumpul kemudian ditabulasi selanjutnya dianalisis secara deskriptif dan ANOVA yang dilanjutkan uji Duncan taraf $95 \%$. Analisis tersebut untuk menjawab permasalahan yang akan dihadapi dan untuk mencapai tujuan terbentuknya kawasan agribisnis perkebunan kakao nasional, sehingga peningkatan produktivitas dan mutu kakao tercapai.

\section{HASIL DAN PEMBAHASAN}

\section{Karakteristik Petani Kakao}

Petani kooperator yang dipilih sebagai sampel adalah petani kakao yang telah mendapat bantuan peremajaan kakao dengan bibit asal SE. Berdasarkan kriteria tersebut terpilih petani kooperator di Wilayah Kabupaten Bone tahun 2010 dan wilayah Kabupaten Luwu tahun 2009. Adapun hasil wawancara dengan petani kooperator disajikan pada Tabel 1.

Petani kakao pada kedua wilayah di Kabupaten Luwu dan Kabupaten Bone termasuk golongan usia produktif. Kondisi tersebut memberikan gambaran kemampuan petani dalam mengadopsi teknologi produksi kakao. Pengalaman petani kakao cukup lama yaitu dengan rataan 8,6 tahun dan 13,75 tahun. Semakin lama pengalaman petani akan memberikan kemampuan dalam mengelola usahatani kakao di lapang. Anggota keluarga petani juga termasuk keluarga yang kurang tanggungannya atau termasuk kategori keluarga sejahtera. Namun hal ini dapat menjadi masalah dalam memenuhi kebutuhan dalam kegiatan 
usahatani. Hal yang bisa dilakukan adalah dengan menyewa tenaga luar keluarga.

Kepemilikan lahan untuk usahatani kakao, petani Luwu lebih luas dibandingkan petani bone. Penguasaan luas lahan tersebut berdampat terhadap jumlah tanaman kakao yang ditanam di lahannya. Demikian juga penerimaan bantuan bibit tanaman kakao SE untuk petani luwu lebih banyak dibandingkan petani di Bone.

Tabel 1. Identitas petani kooperator tanaman kakao SE dan responnya

\begin{tabular}{clcc}
\hline \multirow{2}{*}{ No } & \multicolumn{1}{c}{ Uraian } & \multicolumn{2}{c}{ Keterangan } \\
\cline { 3 - 4 } & & 42 & Kab. Luwu \\
\hline 1 & Umur (th) & 13,75 & 44,8 \\
2 & Pendidikan (th) & $1-5$ & 8,6 \\
3 & Anggota Keluarga (jw/kk) & 0,98 & $2-5$ \\
4 & Luas Lahan (ha) & 850 & 1,95 \\
5 & Jumlah Tanaman (phn) & 438 & 1.800 \\
6 & Jumlah Tanaman SE (phn) & 2010 & 750 \\
7 & Tahun Penanaman SE & & 2009 \\
8 & Pertumbuhan tanaman & Bagus & Jorget tinggi, rebah \\
9 & Hasil Buah kakao & Banyak, kecil & Banyak, kecil \\
10 & Hasil Biji Kakao & Kecil dan kempes & Kecil dan kempes \\
\hline
\end{tabular}

Petani penerima bibit kakao asal SE setelah melakukan penanaman selama 6 tahunan menilai terhadap pertumbuhan tanaman tersebut adalah bagus, jumlah buah banyak. Namun demkian ada beberapa keluhan yang disampaikan oleh petani adalah, jorget tinggi, mudah rebah, ukuran buah kecil, biji kakao kecil dan kempes.

\section{Keragaan Pertumbuhan Awal}

Rataan hasil pengamatan pertumbuhan awal tunas sambung samping pada umur 1 tahun di kabupaten Luwu dan Bone dapat dilihat pada Tabel 2. Dari Tabel 2 dapat disimpulkan bahwa hasil penyambungan tanaman kakao asal SE dengan klon kakao unggul lokal menampakkan kompatibilitas yang berbeda baik dari aspek sumber klon maupun lokasi.

Pertumbuhan sambung samping di lokasi Kabupaten Luwu pertumbuhan terbaik adalah tanaman kakao asal SE disambung dengan klon Sulawesi-2. Jumlah cabang, tinggi tunas sambungan dan diameter batang yang dihasilkan masing-masing adalah 11 cabang, $11,25 \mathrm{~cm}$, dan 2,05 cm. Sedangkan di lokasi Kabupaten Bone pertumbuhan terbaik adalah tanaman kakao asal SE disambung dengan klon Sulawesi-2. Jumlah cabang, tinggi tunas sambungan dan diameter batang yang dihasilkan masing-masing adalah 20 cabang, 275,75 cm, dan 4,66 cm.

Tabel 2. Rataan pertumbuhan awal pengamatan

\begin{tabular}{|c|c|c|c|}
\hline Lokasi dan Nama Klon & Jumlah Cabang & $\begin{array}{l}\text { Tinggi tunas } \\
\text { (cm) }\end{array}$ & $\begin{array}{c}\text { Diameter Batang } \\
\text { Tunas }(\mathrm{cm})\end{array}$ \\
\hline Luwu & 8,81 & 89,25 & 1,62 \\
\hline Sulawesi 1 & 8,75 & 85,25 & 1,54 \\
\hline Sulawesi 2 & 11,00 & 107,75 & 2,05 \\
\hline МCC 01 & 10,00 & 111,25 & 1,55 \\
\hline MCC 02 & 9,50 & 78,75 & 1,70 \\
\hline Bone & 11,94 & 182,50 & 3,04 \\
\hline Sulawesi 1 & 10,75 & 149,25 & 2,95 \\
\hline Sulawesi 2 & 20,75 & 275,75 & 4,66 \\
\hline MCC 01 & 11,25 & 178,25 & 2,71 \\
\hline MCC 02 & 5,50 & 126,75 & 1,83 \\
\hline Rataan & 10,37 & 135,86 & 2,33 \\
\hline
\end{tabular}




\section{Analisis Anova pada Pertumbuhan Tanaman Kakao Sambung Samping}

Pengamatan pertumbuhan tanaman kakao SE yang disambung dengan entris klon kakao unggul Sulawesi Selatan, pada parameter pertumbuhan tinggi tunas sambung samping, jumlah cabang hasil sambung samping, dan diameter batang tunas hasil sambung samping. Adapun hasil analisis sidik ragam disajikan pada Tabel 3,4 dan 5 .

Tabel 3. Hasil analisis sidik ragam pertumbuhan tinggi tunas samsam pada kakao SE

\begin{tabular}{clcc}
\hline \multirow{2}{*}{ No } & \multicolumn{1}{c}{ Perlakuan } & \multicolumn{2}{c}{ Pertumbuhan Tinggi Tunas Pengamatan } \\
\cline { 3 - 4 } & & $22-$ April $(\mathrm{cm})$ & 6 Juni $(\mathrm{cm})$ \\
\hline 1 & SamSam S-1 & $117,25 \mathrm{bc}$ & $142,15 \mathrm{bc}$ \\
2 & SamSam S-2 & $191,75 \mathrm{a}$ & $216,63 \mathrm{a}$ \\
3 & SamSam MCC-1 & $144,75 \mathrm{~b}$ & $169,45 \mathrm{~b}$ \\
4 & SamSam MCC-2 & $102,75 \mathrm{c}$ & $130,35 \mathrm{c}$ \\
5 & Lokasi (Luwu dan Bone) & $137,06(\mathrm{~S})$ & $164,60(\mathrm{~S})$ \\
\hline
\end{tabular}

Keterangan: huruf-huruf yang sama dalam kolom yang sama tidak berbeda nyata pada uji BNJ taraf 5 \% (SAS Versi 9), $(\mathrm{S})=$ siqnifikan, $(\mathrm{NS})=$ Non Siqnifikan

Pertumbuhan tinggi tunas yang diukur dari hasil sambung samping sampai pucuk tanaman pada tanaman kakao SE pengamatan pada 22 April 2017 (11 bulan), memberikan rataan tinggi $137,06 \mathrm{~cm}$. Lokasi kegiatan sebagai petak utama berpengaruh nyata terhadap hasil sambung samping pada pertumbuhan tinggi tanaman kakao SE. Pertumbuhan di lokasi Kabupaten Bone memberikan pertumbuhan yang lebih baik. Perlakuan subplot terbaik dengan teknis sambung samping tanaman kakao SE dengan klon kakao unggul S-2 dan diikuti MCC1.

Hasil analisis sidik ragam pada pertumbuhan tinggi tanaman umur 12 bulan (pengamatan 6 Juni 2017), bahwa lokasi sebagai petak utama memberikan pengaruh nyata terhadap hasil sambung samping. Yang terbaik pada lokasi kegiatan di Kabupaten Bone. Adapun rataan pertumbuhan tinggi tanaman kakao SE hasil sambung samping mencapai $164,60 \mathrm{~cm}$. perlakuan terbaik pada sambung samping dengan kakao klon S-1 dan diikuti oleh MCC-1.

Pertumbuhan cabang tunas yang diukur dari hasil sambung samping sampai pucuk tanaman pada tanaman kakao SE pengamatan pada 22 April 2017 (11 bulan), memberikan rataan jumlah cabang 10,37 cabang/rumpun. lokasi sebagai petak utama berpengaruh nyata terhadap hasil sambung samping pada pertumbuhan cabang tanaman sambung samping. Pertumbuhan cabang di lokasi Kab. Bone memberikan pertumbuhan yang lebih baik. Perlakuan subplot terbaik dengan teknis sambung samping tanaman kakao SE dengan klon kakao unggul S-2 dan diikuti oleh S-1.

Tabel 4. Hasil analisis sidik ragam pertumbuhan jumlah cabang samsam pada kakao SE

\begin{tabular}{clcc}
\hline \multirow{2}{*}{ No } & \multicolumn{1}{c}{ Perlakuan } & \multicolumn{2}{c}{ Pertumbuhan jumlah cabang Pengamatan } \\
\cline { 3 - 4 } & & 22-April (cabang) & 6 Juni (cabang) \\
\hline 1 & SamSam S-1 & $9,75 \mathrm{~b}$ & $9,88 \mathrm{a}$ \\
2 & SamSam S-2 & $15,88 \mathrm{a}$ & $11,50 \mathrm{a}$ \\
3 & SamSam MCC-1 & $10,63 \mathrm{ab}$ & $9,50 \mathrm{a}$ \\
4 & SamSam MCC-2 & $7,50 \mathrm{c}$ & $12,65 \mathrm{a}$ \\
5 & Lokasi (Luwu dan Bone) & $10,37(\mathrm{~S})$ & $8,38(\mathrm{NS})$ \\
\hline
\end{tabular}

Keterangan: huruf-huruf yang sama dalam kolom yang sama tidak berbeda nyata pada uji BNJ taraf $5 \%$ (SAS Versi 9), (S) = siqnifikan, (NS) = Non Siqnifikan

Hasil analisis sidik ragam pada pertumbuhan cabang tanaman umur 12 bulan (pengamatan 6 Juni 2017), bahwa lokasi kegiatan sebagai petak utama tidak berpengaruh nyata terhadap hasil sambung samping. Adapun secara nominal perlakuan terbaik adalah sambung samping dengan MCC-2. Demikian juga nilai rataan pertumbuhan cabang mengalami penurunan dari 10,37 cabang menjadi 8,38 cabang. Hal tersebut terjadi, dikarenakan selama 
pemeliharaan petani melakukan pemeliharaan dengan melakukan pemangkasan cabang air.

Diameter batang tanaman kakao SE diukur pada $10 \mathrm{~cm}$ dari tautan tunas sambung samping dengan entris klon kakao unggul. Pertumbuhan diameter batang tunas rataanya mencapai 2,33 cm (pengamatan tanggal 22 April 2017). Lokasi kegiatan sebagai petak utama dalam penelitian ini berpengaruh nyata, loaksi kegiatan Kabupaten Bone lebih Baik. Adapun anak petak perlakuan sambung samping dengan sumber entris klon kakao unggul lokal juga berbeda nyata. Sambung samping dengan sumber entris kakao klon S-2 menunjukan terbaik yaitu mencapai 3,36 cm dan diikuti S $-12,23 \mathrm{~cm}$.

Tabel 5. Hasil analisis sidik ragam pertumbuhan diameter batang tunas samsam pada kakao SE

\begin{tabular}{clcc}
\hline No & \multicolumn{1}{c}{ Perlakuan } & \multicolumn{2}{c}{ Pertumbuhan Diameter Tunas Pengamatan } \\
\cline { 3 - 4 } & & $22-$ April $(\mathrm{cm})$ & 6 Juni $(\mathrm{cm})$ \\
\hline 1 & SamSam S-1 & $2,25 \mathrm{~b}$ & $2,97 \mathrm{~b}$ \\
2 & SamSam S-2 & $3,36 \mathrm{a}$ & $4,08 \mathrm{a}$ \\
3 & SamSam MCC-1 & $2,13 \mathrm{~b}$ & $2,86 \mathrm{~b}$ \\
4 & SamSam MCC-2 & $1,76 \mathrm{c}$ & $2,48 \mathrm{c}$ \\
5 & Lokasi (Luwu dan Bone) & $2,33(\mathrm{~s})$ & $3,10(\mathrm{~S})$ \\
\hline
\end{tabular}

Keterangan: huruf-huruf yang sama dalam kolom yang sama tidak berbeda nyata pada uji BNJ taraf $5 \%$ (SAS Versi 9), $(\mathrm{S})=$ siqnifikan, $(\mathrm{NS})=$ Non Siqnifikan.

Rataan pertumbuhan diameter batang pada pengamatan tanggal 6 Juni mencapai 3,10 $\mathrm{cm}$, lokasi kegiatan sebagai petak utama berpengaruh nyata terhadap pertumbuhan tanaman sambung samping. Sumber entris klon kakao unggul sebagai anak petak, hasil analisis sidik ragam yang terbaik adalah perlakuan sambung samping dengan S-2.
Ternyata ada sebagian petani yang telah mengambil inisiatif, melakukan sambung samping tanaman kakao SE dengan menggunakan klon yang mereka sukai misalnya klon S1, S2, dan MCC 02. Adapun hasil pengamatan pada pembentukan buah disajikan pada Tabel 6.

Tabel 6. Rataan produksi kakao sambung samping klon S-1, S-2, dan MCC02 pada umur 3 tahun di kabupaten Luwu dan Bone

\begin{tabular}{lccccc}
\hline \multirow{2}{*}{ Komponen Pengamatan } & \multicolumn{3}{c}{ Kabupaten Luwu } & \multicolumn{2}{c}{ Kabupaten Bone } \\
\cline { 2 - 6 } & $\mathrm{S}-1$ & $\mathrm{~S}-2$ & MCC-2 & S-1 & S-2 \\
\hline Jumlah buah/pohon/tahun & 25,75 & 26,50 & 24,64 & 28,33 & 33,22 \\
Jumlah dipanen/pohon/tahun & 24,30 & 24,38 & 23,39 & 26,81 & 30,85 \\
Jumlah buah rusak/pohon/thn & 1,45 & 2,12 & 1,25 & 1,52 & 2,37 \\
Produksi (kg)/ha/thn 900 tan & 1.489 & 1.494 & 1.434 & 1.643 & 1.891 \\
\hline
\end{tabular}

Perbaikan mutu yang dilakukan oleh petani pada tanaman kakao asal SE dengan klon kakao unggul lokal sudah banyak dilakukan oleh petani. pengamatan yang dilakukan pada hasil sambung umur tanaman 3 tahun. Adapun klon yang diamati adalah tanaman kakao SE disambung dengan klon Sulawesi-1, Sulawesi-2 dan MCC-2. Produksi buah kakao berkisar antara 14,64 - 23,22 buah/pohon selama 2 bulan pengamatan, sedangkan yang dipanen pada pengamatan tersebut antara $5-9,20$ buah/pohon dan serangan hama penyakit atau menjadi rusak tidak bisa dipanen mencapai $1,25-2,37$ buah/pohon.

\section{Respon Petani terhadap Teknologi}

Teknologi produksi kakao untuk meningkatkan kualitas tanaman kakao SE dengan menggunakan teknologi sambung samping dengan klon kakao unggul. Penggunaan entris klon kakao unggul pada tanaman kakao SE hanya diujicobakan 5 petani di lokasi pengembangan kakao yaitu Kabupaten Bone dan Luwu. Sehingga untuk mengetahui respon petani, maka pada waktu temu lapang dilakukan beberapa pertanyaan kepada pesertanya. Adapun hasil respon petani disajikan pada Tabel 7. 
Petani kakao peserta temu lapang pada tanggal 30 Agustus 2017 di Kelompok Tani Lembah Subur, Kelurahan Matarropuli, Kecamatan Bengo, Kabupaten Bone, Sulawesi
Selatan berjumlah 30 petani kakao. Setiap peserta temu lapang mendapat kesempatan yang sama memperoleh pertanyaan yang sama sebagai responya.

Tabel 7. Respon petani terhadap teknologi sambung samping pada Temu Lapang di Kab. Bone

\begin{tabular}{|c|c|c|c|}
\hline No & Uraian & Jumlah Petani & Presentase (5) \\
\hline 1 & $\begin{array}{l}\text { Petani mengetahui teknologi sambung samping } \\
\text { pada tanaman kakao SE }\end{array}$ & 26 & 86,67 \\
\hline 2 & $\begin{array}{l}\text { Petani sudah melakukan sambung samping pada } \\
\text { tanaman kakao SE }\end{array}$ & 18 & 60,00 \\
\hline 3 & Petani tahu sumber entris kakao & 14 & 46,67 \\
\hline 4 & Jenis sumber entris dari klon & $\begin{array}{l}\text { Sulawesi-1 dan } \\
\text { Sulawesi-2 }\end{array}$ & - \\
\hline 5 & Petani mau melakukan teknis sambung samping & 30 & 100 \\
\hline
\end{tabular}

Hasil penilaian atau wawancara dengan petani memperoleh, petani kakao peserta mengetahui tentang teknologi sambung samping sebesar 26 petani atau 86,67\%. Petani kakao sebagian besar mengetahui tentang teknologi sambung samping yang dapat digunakan untuk meningkatkan produksi kakao SE. Dari sejumlah petani tersebut, hanya 18 petani atau $60 \%$ yang sudah melakikan teknologi sambung samping. Sumber entris yang digunakan oleh petani berasal dari entris Sulawesi-1 dan Sulawesi 2.

Walaupun petani sudah tahu dan melakukan teknis sambung samping, namun petani yang bisa menyebutkan jenis sumber entris pupuk organik baru 14 petani atau 46,67\%. Penggunaan sumber etris klon kakao unggul lokal diminati oleh 30 petani atau $100 \%$. Walaupun petani tersebut tidak tahu dan tidak bisa menyebutkan semua jenis sumber etris.

\section{Analisis Biaya Sambung Pucuk dan Sambung samping Tanaman Kakao}

Perbaikan mutu tanaman dan biji kakao dapat dilakukan dengan peremajaan dengan tanaman baru dan juga dapat dilakukan teknologi sambung samping pada tanaman yang sudah ada/tua kurang menjadi harapanya. Kedua teknologi tersebut memerlukan biaya yang berbeda. Adapun analisis biaya teknologi perbaikan mutu tanaman dan biji kakao disajikan pada Tabel 8 .
Berdasarkan Tabel 8 menunjukan bahwa perbaikan mutu tanaman dan biji kakao dengan perlakuan peremajaan dengan tanaman baru memerlukan biaya yang lebih banayak dibandingkan dengan teknologi sambung samping pada tanaman yang sudah ada atau tanaman yang tidak memenuhi harapan. Biaya peremajaan tanaman kakao dengan bibit sambung pucuk mencapai Rp. 13.660.000/ha pada tahun pertama. Komponen biaya terbesar adalah pada biaya pembuatan lubang tanam dan penanaman mencapai Rp. 10.000.000/ha atau $73,21 \%$ dari total biaya. Sedangkan komponen lainya adalah biaya dalammenyediakan bibit sambung pucuk dengan klon unggul. Penyediaan bahan tanam ini bisa dilakukan dengan pembelian pada penangkar bibit kakao maupun menyediakan sendiri.

Sedangkan perbaikan mutu tanaman dan biji kakao pada tanaman yang sudah ada dengan teknologi sambung samping memerlukan biaya yang lebih sedikit. Hal tersebut disebabkan tanaman yang sudah ada tinggal dilakukan sambung samping dengan entris klon yang menjadi harapan kita. Komponen biaya yang terbesar adalah biaya sambung samping dan pemeliharaannya. Namun apabila kegiatan sambung sampping ini dilakukan sendiri, maka biaya ini bisa dijadikan saving ataau biaya implisif. 
Tabel 8. Analisis biaya kakao sambung pucuk dan sambung samping dalam satu tahun

\begin{tabular}{rcc}
\hline \multicolumn{1}{c}{ Jenis Kegiatan } & Sambung Pucuk & Sambung Samping \\
\hline Bahan & & \\
1. Polibag & 200.000 & $\mathrm{X}$ \\
2. pupuk kandang & 1.500 .000 & 1.000 .000 \\
3. pupuk NPK & 115.000 & 230.000 \\
4. Pestisida & 45.000 & 45.000 \\
5. Gunting, pisau okulasi, plastic, tali dsb & 250.000 & 250.000 \\
6. Entris & 150.000 & 150.000 \\
Upah Kerja & & $\mathrm{X}$ \\
1. Pengisian polibag & 50.000 & $\mathrm{X}$ \\
2. Pemeliharaan bibit di pesemaian & 450.000 & $\mathrm{X}$ \\
3. Sambung pucuk & 450.000 & $\mathrm{X}$ \\
4. Penanaman & 150.000 & 1.500 .000 \\
5. Sambung Samping & $\mathrm{X}$ & $\mathrm{X}$ \\
6. Pembuatan Lubang Tanam & 5.000 .000 & $\mathrm{X}$ \\
7. Penanaman & 5.000 .000 & 1.500 .000 \\
8. pemeliharaan tanaman di lahan & 300.000 & \\
$\quad$ (penyiraman, pemupukan, penyiangan, & & \\
$\quad$ pengendalian hama/penyakit, & & 4.675 .000 \\
\hline
\end{tabular}

\section{KESIMPULAN}

Petani yang mengusahakan tanaman kakao SE dan melakukan sambung samping dengan klon kakao unggul lokal mempunyai karakteristik usia produktif dan didukung tingkat pendidikan serta pengalaman yang memadai. Pertumbuhan tanaman kakao SE yang disambung dengan klon kakao unggul lokal jenis dan lokasi memberikan pengaruh beda nyata. Demikian juga petani yang telah mencoba menyambung secara mandiri tanaman kakao SE dengan klon kakao unggul lokal memberikan hasil yang lebih baik. Respon petani terhadap tanaman kakao SE yang disambung dengan sumber entris klon kakao unggul mencapai $60 \%$ sudah melakukan sambung samping. Produktivitas kakao SE yang disambung samping mencapai $1.988 \mathrm{~kg} / \mathrm{ha}$. Perbaikan tanaman kakao SE dengan sambung samping memerlukan biaya mencapai Rp. 4.675.000/ha, lebih murah dibandingkan dengan penanaman ulang dengan sambung pucuk mencapai Rp. 13.660.000/ha.

\section{DAFTAR PUSTAKA}

Anonimous. 2010. Klon unggul kakao generasi ketiga- Keragaan klon unggul Sulawesi 1- Rehabilitasi dengan sambung samping-entres kakao cukup untuk mendukung rehabilitasi di 4 propinsiKlon-klon unggul kakao-teknologi SE kakao sistem padat. http// pengawasbenihtanaman. blogspot. com, (Rabu 10 Februari 2010).

Basir, M.N., P. Tandisau, Sahardi, Sunanto, Nurdiah. 2013. Identifikasi Kebutuhan teknologi spesifik lokasi Provinsi Sulawesi Selatan.Laporan BPTP Sulsel tahun 2013.

Dinas Perkebunan Propinsi Sulsel. 2009. Laporan Tahun 2009. Dinas Perkebunan Propinsi Sulawesi Selatan.

Ditjenbun.2004. Statistik Perkebunan Indonesia. Direktorat Jenderal Perkebunan, Jakarta.

Erwiyono, R., Aris Wibawa,Pujiyanto, John Bako Baon, dan Soetanto Abdullah. 2000. Pengaruh Sumber Bahan Organik Terhadap Keefektifan Pemupukan Kompos pada Kakao dan Kopi. Warta Puslit Kopi dan Kakao Vol. 16 (1) :4549.

Ditjenbun.2004. Statistik Perkebunan Indonesia. Direktorat Jenderal Perkebunan, Jakarta.

Hulupi, R. 1999, Bahan tanaman kopi yang sesuai untuk kondisi Agroklimat di Indonesia. 
Warta Pusat Penelitian Kopi dan Kakao. Jember. Vol 15 (I) $64-85$.

Kadir,S., Jermia Limbongan, dan Farida Arief. 2011. Pengaruh Penggunaan Bahan Organik In Situ Terhadap Pertumbuhan dan Produksi Tanaman Kakao (Theobroma cacao L.) di Sulawesi Selatan. Prosiding Seminar Nasional Akselerasi Pembangunan Pertanian dan Pedesaan Berbasis Inovasi. Balai Besar Pengkajian dan Pengembangan Teknologi Pertanian, Manokwari 28 September 2011.Halaman 371-376.

Kiswanto, B. Wijayanto, dan A. Soim. 2008. Teknologi Budidaya Kopi Poliklonal. BPTP Lampung, Balai Besar Pengkajian dan Pengembangan Teknologi Pertanian. $17 \mathrm{hlm}$.

Limbongan, J., Syafruddin Kadir, Dharmawida Amiruddin ,Basir Nappu, dan Paulus Sanggola. 2010. Pengkajian Penggunaan Bahan Tanaman Unggul Menunjang Program RehabilitasiTanaman Kakao di Sulawesi Selatan. Laporan Tahun 2010 BPTP Sulawesi Selatan

Limbongan,J. dan Syafruddin Kadir. 2011. Kajian Tingkat Keberhasilan Sambungan Pada PenerapanTeknologi Sambung Samping Tanaman Kakao di Sulawesi Selatan. Prosiding Seminar Nasional Akselerasi Pembangunan Pertanian dan Pedesaan Berbasis Inovasi. Balai Besar Pengkajian dan Pengembangan Teknologi Pertanian, Manokwari 28 September 2011. Halaman 377-381.

Limbongan, J. 2012. Pengkajian Pola Penerapan Inovasi Pertanian Spesifik LokasiTanaman Kakao di Sulawesi Selatan. Jurnal AgroSainT UKI Toraja Vol. III No. 2 : 295 - 301.

Limbomgan J., Fadjry Djufry, Sunanto, Arini, Since Erna Lamba. 2015. Evaluasi Tanaman kakao Asan Perbanyakan Somatic Embriogensis. Laporan KKP3SL 2015.

Limbomgan J., M. yasin, Sunanto, Nur Ajijah, Arini. 2016. Pengkajian Teknologi Sambung Samping dalam Peningkatan Produksi dan Mutu Kakao Asal SE di Sulawesi Selatan. Laporan KKP3SL 2016
Mariska, I., dan S. Rahayu, 2011. Pengadaan Bibit Tanaman Tebu melalui Kultur Jaringan.

Mawardi, S. 1986. Memilih klon-klon unggul kopi yang sesuai untuk daerah tertentu. Warta Pusat Penelitian Perkebunan Jember. No. 3- 48 hlm.

Purwono, 2011. Keragaan Varietas dan Kesesuaian Lahan untuk Pengembangan Tanaman Tebu. Materi Bimbingan Teknis Pembibitan Tebu, 23 - 25 Mei 2011. Bogor

Pujianto, 1996.Status bahan organik tanah pada perkebunan kakao dan kakao di Jawa Timur.Warta Pusat Penelitian Kakao dan Kakao.Vol.12 (2).Pusat Penelitian Kakao dan Kakao. Assosiasi Penelitian Perkebunan Indonesia, Jember, 147 hal.

Rubiyo. 2001. Peranan bahan tanam unggul untuk meningkatkan produktivitas dan mutu kakao lindak di Propinsi Bali. Prosiding Seminar Nasional Pengembangan Teknologi Pertanian Dalam Upaya Optimalisasi Potensi Wilayah Mendukung Otonomi Daerah. Denpasar 5 Sep 2001. Pusat Penelitian dan Pengembangan Sosial Ekonomi Pertanian. Bogor.Halaman 254-259.

Setyorini Diah. 2005. Pupuk Organik TingkatkanProduksi Pertanian. Warta Penelitian dan Pengembangan Pertanian Vol 27 (.6).

Sophia D.F., Pudji Rahardjo. 2007. Prospek Usaha Perbenihan Kakao. Warta Pusat Penelitian Kopi dan Kakao Indonesia. Vol. 23 No. 2. Halaman 62-70.

Suhendi, D. 2008. Rehabilitasi tanaman kakao: Tinjauan potensi, permasalahan, dan rehabilitasi tanaman kakao di desa primatani Tonggolobibi. Prosiding Seminar Nasional Pengembangan Inovasi Lahan Marginal. Pusat Penelitian Kopi Dan Kakao Indonesia hlm 335346.

Sumitro, R. 2006. Kebijakan Pengembangan Industri Pengolahan dan Pemasaran Kopi. Bina Pengolahan dan Pemasaran Hasil Pertanian, Departemen Pertanian. Jakarta.

Sunanto, M. Azis Bilang, dan Sahardi. 2006. Karakteristik dan Kelayakan Usahatani Kakao (Studi Kasus di dusun Wonosari Kecamatan Kamanre Kabupaten 
Palopo). Prosiding Seminar Nasional Hasil-Hasil Penelitian dan Pengkajian Spesifik Lokasi Tahun 2006 di Makassar. Balai Besar Pengkajian dan Pengembangan Teknologi Pertanian, halaman 620-627.

Tabrang Hasanuddin, Gusti Aidar, NR dan Nurdiah Husnah, 2006. Analisis Kelayakan Usahatani Kakao dengan Menggunakan Pupuk Organik di Kabupaten Polman.Prosiding Seminar Nasional Hasil-Hasil Penelitian dan Pengkajian Spesifik Lokasi Tahun 2006 di Makassar. Balai Besar Pengkajian dan Pengembangan Teknologi Pertanian, halaman 634-664.

Tandisau, P., Paulus D.R., dan M. Paembonan. 2006. Peranan Teknologi Pemupukan dan Pemangkasan Dalam Rangka Perbaikan Mutu Tanaman Kakao, Prosiding Seminar Nasional Hasil-Hasil Penelitian dan Pengkajian Spesifik Lokasi Tahun 2006 di Makassar. Balai Besar Pengkajian dan Pengembangan Teknologi Pertanian, halaman 575-585.

Tandisau, P., Paulus D.R., dan M. Paembonan. 2013. Pengembangan Agribisnis Tebu Asal Kultur Jaringan di Sulawesi Selatan. Laporan Kegiatan. Balai Pengkajian Teknologi Pertanian Sulawesi Selatan. Makassar.

Winarno, H. 1995. Klon-klon unggul untuk mendukung klonalisasi kakao lindak. Warta Puslit Kopi dan Kakao, 11 (2) :7781 . 